\title{
KONCEPT EŠALONIRANJA OGNJEV IN SISTEMI OGNJENE PODPORE V SLOVENSKI VOJSKI
}

\section{ECHELONMENT OF FIRES AND INDIRECT FIRE SYSTEMS IN THE SLOVENIAN ARMED FORCES}

Povzetek V članku se ukvarjamo s konceptom ešaloniranja ognjev. Zmogljivosti sistemov za ognjeno podporo pri majhnih vojskah so omejene, zato je pravilna in smotrna upraba koncepta ešaloniranja ognjev bistvena za uspeh na bojišču. Hkrati pa predvsem manjše članice Nata upravičeno pričakujejo, da bodo v operacijah zavezništva deležne tudi učinkov sistemov združene ognjene podpore, ki jih imajo na voljo velike države. V nadaljevanju predstavimo koncept ešaloniranja ognjev in njegov vpliv na oblikovanje dobrega sistema ognjene podpore na taktični ravni, od ravni voda do brigade. Nazadnje pa pogledamo na zmogljivosti Slovenske vojske in njenih sistemov za posredne ognje znotraj širšega sistema ognjene podpore Slovenske vojske in združene ognjene podpore zavezništva ter navedemo nekaj ključnih ugotovitev, ki bi lahko služile kot premislek pri nadaljnji gradnji zmogljivosti Slovenske vojske.

Ključne Slovenska vojska (SV), manever, ešaloniranje ognjev, artilerija, minometi, ognjena besede podpora, združena ognjena podpora, sistemi za posredne ognje.

Abstract The article discusses the concept of echelonment of fires. Small armed forces such as the Slovenian Armed Forces (SAF) have a limited joint fires capability. Therefore, in order to succeed on the battlefield, they have to correctly apply the principles of echelonment of fires. Additionally, smaller NATO members rightfully expect to receive some of the Joint Fires Effects from larger member armies in the Joint Operational Environment. The article looks at the Joint Fire Support and indirect fire systems, and what the terms mean for small NATO member states with limited capabilities. It then goes on to present the concept of echelonment of fires and some key terms within the concept. Lastly, it looks at SAF capabilities through the echelonment of fires concept and Indirect Fire Systems. The author also puts forward some suggestions for future development of SAF capabilities.

Key words Slovenian Armed Forces, manoeuvre, echelonment of fires, artilery, mortars, fire support, joint fire support, indirect fire systems. 
Uvod Slovenska vojska je avgusta 2015 prvič po letu 1997 opravila pripravljalno streljanje z minometi $60 \mathrm{~mm}$, ki so bili iz operativne uporabe umaknjeni leta 2001 (Pišlar, 2015, str. 20). To pomeni, da je bila od takrat brez minometne ognjene podpore na najnižjih taktičnih ravneh voda in čete. Nekateri bodo sicer trdili, da ni tako in da so bili minometi te vrste nadomeščeni z bombometi (ročnimi, podcevnimi in avtomatskimi), s čimer pa se ne strinjamo, razlaga je zapisana v točki 4. Vzroki, da so bili minometi leta 2001 umaknjeni iz uporabe, so nedvomno kompleksni, ostaja pa dejstvo, da je SV imela manko v eni ključnih zmogljivosti.

Razmere v ognjeni podpori v SV nikakor niso zavidljive. Uvod v koncept združene ognjene podpore $\mathrm{SV}^{1}$ ugotavlja, da je »/.../ v SV sodelovanje enot bojne podpore $\mathrm{z}$ bojnimi enotami omejeno« (Koncept, 2015, str. 4). Bistveni pa sta vprašanji, kaj z združeno ognjeno podporo v SV sploh želimo doseči in ali sploh lahko govorimo o združeni ognjeni podpori na ravni SV. Odgovor nanju zahteva jasno vizijo delovanja sistema ognjene podpore od ravni voda do ravni brigade.

Namen članka je preprost: oblikovati pogled SV na vlogo in nalogo sistemov, ki zagotavljajo posredne ognje za ognjeno podporo na taktični ravni od ravni voda do brigade. V članku bomo to naredili z razlago koncepta ešaloniranja ognjev in njegovega pomena za uspeh ognja in manevra na bojišču. Najprej bomo povzeli nekaj teoretičnih podlag, nujnih za razumevanje vloge ognjene podpore na bojišču, in opredelili pojme, ki jih srečujemo pri obravnavi združene ognjene podpore $\mathrm{v}$ majhnih oboroženih silah, kakršna je SV. Nato bomo na zagotavljanje ognjev za manever pogledali z vidika koncepta ešaloniranja ognjev in njegove vloge pri zagotavljanju razmer za uspeh manevra. Nazadnje pa bomo prek koncepta ešaloniranja ognjev in sistemov posredne ognjene podpore analizirali stanje »združene« ognjene podpore v SV.

\section{ZDRUŽENA OGNJENA PODPORA}

\section{a) Teoretična podlaga}

Clausewitz je zapisal »/.../ vojaška aktivnost ni nikoli usmerjena samo proti materialnim sredstvom, vedno je hkrati usmerjena tudi proti moralni sili, ki jim daje življenje, in teh dveh (materialne in moralne sile) ne moremo ločevati« (Johnson, 2000, str. 8). Na podlagi tega je Schneider razvil model procesa uničevanja človeške volje v boju (glej sliko 1), za kar uporablja prispodobe fizične, kibernetske in moralne domene. Poenostavljeno povedano gre enota $\mathrm{v}$ boj kot kohezivna celota, nato pa $\mathrm{s}$ časom, predvsem zaradi hitrosti uničevanja, njena kohezivnost pada in enota postaja vse bolj dezorganizirana. Dezorganizacija vpliva predvsem na funkcije poveljevanja, kontrole in komunikacije, ki zagotavljajo organizacijo enote. Če te še naprej slabijo kot posledica nadaljnjega uničevanja, dezorganizacija preide $\mathrm{v}$ dezintegracijo oziroma popoln zlom kohezije in organizacije enote (Johnson, 2000, str. 9).

Koncept je bil podpisan in velja. Ni pa še bil uveljavljen in je v pripravi za eksperiment, zato ga v članku niti ne obravnavamo. Tu samo povzemamo ugotovitve o trenutnem stanju ognjene podpore $v S V$. 
Slika 1:

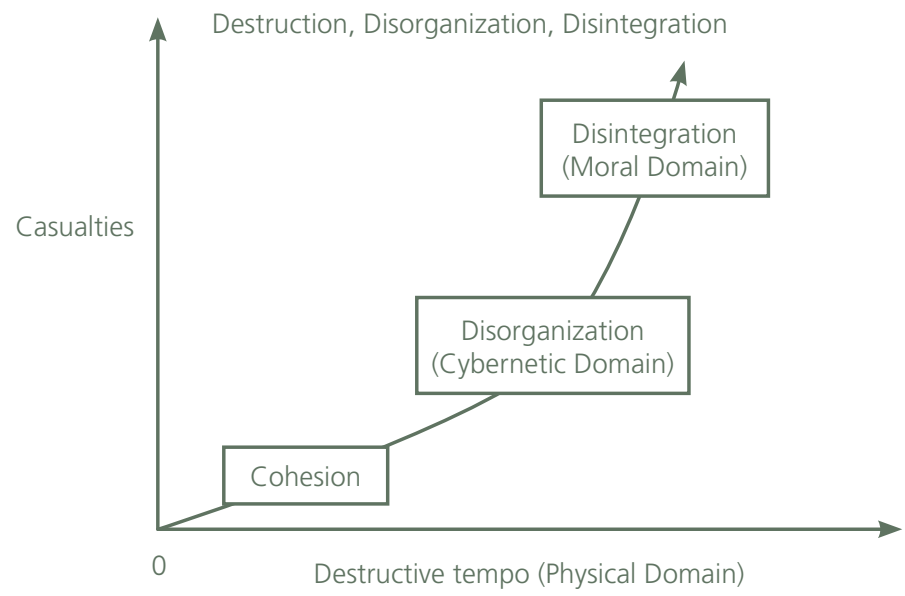

Dr. Schneider's model

V Schneiderjevem modelu je proces uničevanja nespremenljiv dejavnik na bojišču in vzrok izgube volje do bojevanja. Pri tem je vloga poveljnika na bojišču, da vzpostavi, vzdržuje in regenerira primarne skupine (enote) kot sredstvo za vzdrževanje volje do bojevanja. Ko so s časom oborožitveni sistemi postajali zmogljivejši in proces uničevanja vse učinkovitejši, so vojaške enote postajale vse manjše, bolj razpršene in so izgubljale organizacijsko kohezivnost. Prihajalo je do dezintegracije. Da bi zmanjšale učinke dezintegracije in osredotočile delovanje razpršenih sil, so vojaške organizacije izboljševale poveljevanje, kontrolo in komunikacijo ter organizacijsko strukturo. Združevanje ognjev z manevrom je bil eden izmed načinov, kako so vojske skušale osredotočiti bojno moč na točki odločitve (Johnson, 2000, str. 6-16).

Ogenj in manever se nanašata na uporabo vseh posrednih in neposrednih ognjev vojaške formacije pri združenem bojevanju rodov, s katerimi ta skuša doseči prednost na bojišču. Manever kot kombinacija ognja in premika pa je značilen za manevrsko enoto in se nanaša na njeno sposobnost uporabe neposrednih ognjev v podpori premiku enega dela enote. Razlikovanje med ognjem in manevrom je pomembno, ko govorimo o vlogi ognjene podpore na bojišču. Glede na to, da sta ogenj in manever primarna načina doseganja pozicije prednosti na bojišču, s katere bo enota, ki izvaja združeno bojevanje rodov, dosegla zase ugodno odločitev, je razumljivo, da sta ogenj in manever dve neločljivi sili (Johnson, 2000, str. 19).

Če torej povzamemo, Schneiderjev model pojasni vzroke za povečevanje ognjene moči vojaških formacij. Kot v svoji študiji ugotavlja Johnson, povečevanje ognjene moči in večanje natančnosti orožij vodita v še večjo disperzijo sovražnika in delovanje v vse manjših enotah, kar povzroča dezorganizacijo in dezintegracijo, zaradi česar 
morajo tudi lastne sile delovati v vse manjših enotah, da bi lahko odgovorile na disperzijo sovražnika. To hkrati pomeni, da morajo imeti lastne enote na vseh nižjih taktičnih ravneh dostop do ustreznih sistemov ognjene podpore, da bi lahko ustvarile dovolj bojne moči na točki odločitve (Johnson, 2000, str. 25).

\section{b) Terminologija}

Na področju ognjene podpore je nekaj terminoloških zadreg. S prevzemom Natovih doktrin in standardov so se v SV pojavili nekateri termini, za katere v slovarjih in terminoloških zbirkah ne najdemo neposrednih prevodov, niti jih ni v veljavni doktrini SV (2006).

Združene ognje(angl.joint fires) zavezništvo opredeljuje kot»/.../ ognje, ki se izvajajo med uporabo sil, sestavljenih iz dveh ali več komponent (zvrsti), v koordinirani akciji za dosego skupnega cilja« (AAP-6, 2013, str. 2-J-1)2. Združeno ognjeno podporo (angl. joint fire support) pa kot $» / . . . /$ koordinirano in integrirano uporabo vseh oborožitvenih platform, ki zagotavljajo ognje ${ }^{3}$, da bi dosegli želene učinke na zemeljske cilje v podpori kopenskih operacij v celotnem spektru spopadov. Obsega integracijo posrednih ognjev in učinkov z namenom vplivanja na sovražnikove sile, infrastrukturo in funkcije« (AartyP-5(A), 2011, str. 1-1) ${ }^{4}$.

Ko v zavezništvu govorijo o združenem, govorijo o »/.../ aktivnostih, delovanju in organizacijah, v katerih sodelujejo elementi vsaj dveh različnih zvrsti oboroženih sil« (AAP-6, 2013, str. 2-J-1). Znotraj zavezništva pa imajo majhne vojske, kot so na primer oborožene sile Litve, Latvije, Estonije in Slovenije, zelo omejene zmogljivosti po zvrsteh (Hacket, 2015, str. 87, 88, 111-114). SV zvrsti formalno sploh ne pozna, pomorstvo in letalstvo sta samo rodova znotraj enotne organizacije vojske (ZObr, 2004, 40. člen).

Doktrina SV (2006) ne pozna pojmov združeni ognji in združena ognjena podpora, opredeljuje zgolj ognjeno podporo, in sicer kot »/.../ skupno in usklajeno uporabo ognjenega delovanja kopenskih, mornariških in zračnih bojnih sistemov in delovanja ofenzivnih sistemov elektronskega bojevanja ter neubojnih sredstev na cilje na kopnem ali morju« (Furlan in drugi, 2006, str. 99).

Ko torej govorimo o pojmu združeno na primeru majhnih vojsk, se je treba zavedati, da imajo te vojske, četudi poznajo različne zvrsti oboroženih sil, precejšnje omejitve v vseh zvrsteh, še posebno pa v zmogljivostih mornariške in letalske komponente. Pri SV pa sploh težko govorimo o združeni ognjeni podpori, saj nima zvrsti in lahko o tej podpori govorimo le, ko SV s svojimi zmogljivostmi deluje v zavezništvu.

\footnotetext{
Fires applied during the employment of forces from two or more components, in coordinated action toward a common objective.

3 Ti vključujejo tudi kopenske, zračne in mornariške posredne ognje.

4 JFS is the coordinated and integrated employment of all weapon platforms delivering fires to achieve the required effects on ground targets to support land operations in the full spectrum of conflict. It encompasses the integration of indirect fires and effects in order to influence the adversary forces, installations or functions.
} 
Slika 2:

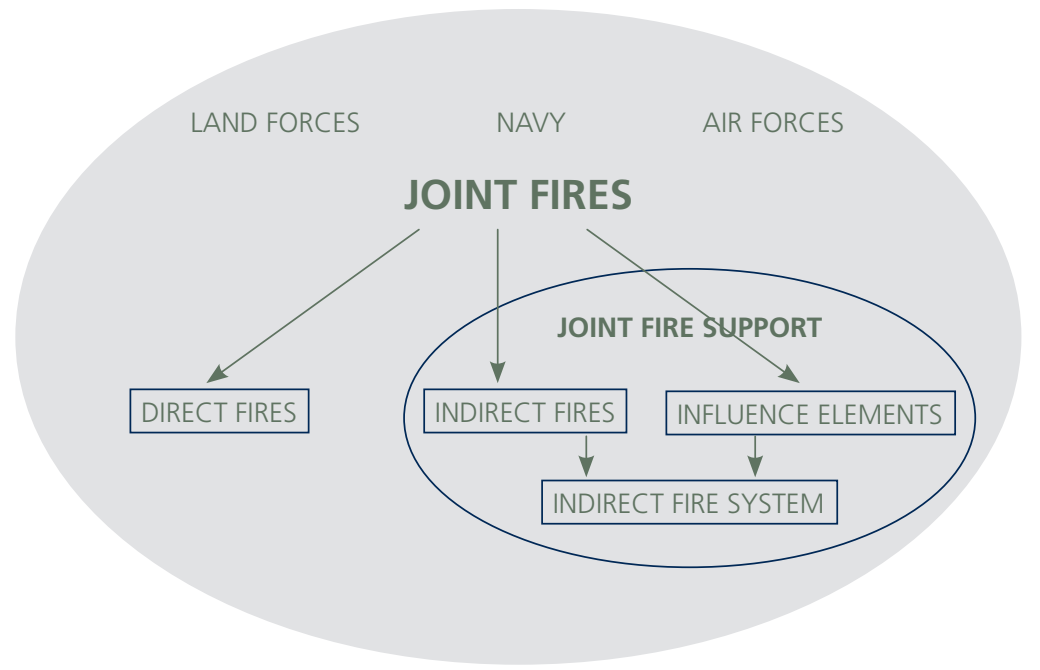

V zavezniški doktrini se pojavlja tudi izraz indirect fire support (Stanag 2484(2), Stanag 2605, Stanag 2490), za katerega pa pri nas nimamo uradnega prevoda niti ni Natove definicije izraza. V kontekstu Natovih dokumentov je po avtorjevem mnenju najprimernejši prevod posredna ognjena podpora, ki pomeni ognje, ki jih za manever zagotavljajo kopenski sistemi za posredno delovanje. Tudi pregled izrazov, opredeljenih v Vojni enciklopediji (druga izdaja), avtorju ni dal jasnega odgovora na terminološke zadrege. Izraz vatrena podrška (Gažević, 1975, str. 330) je v njej opredeljen kot sinonim za Natov fire support, taka je tudi razlaga pojma, medtem ko za pojem (ne)posredna podrška najdemo razlago, da gre za podporo, ki (ne)posredno vpliva na potek boja (Gažević, 1973, str. 786). Izraza, ki bi ustrezal Natovemu indirect fire support, v enciklopediji ne najdemo.

$\mathrm{V}$ tem članku bomo v delu, ki se nanaša na SV, zato govorili o združeni ognjeni podpori, in sicer z jasnim zavedanjem, da govorimo le o zmogljivostih različnih rodov SV ter da so te $\mathrm{v}$ mornariški in zračni komponenti zelo omejene. Poleg tega bomo za izraza indirect fire support ter indirect fire system uporabljali termina posredna ognjena podpora in sistemi za posredni ogenj.

\section{c) Sistemi za posredni ogenj}

Zavezniška taktična doktrina sistemov za posredni ogenj opredeljuje, kateri so ti sistemi po posameznih zvrsteh. V kopensko komponento zavezništvo šteje minomete ter cevno in raketno artilerijo, v zračno komponento pa letala z zmogljivostmi protipovršinskega delovanja (na morju), onemogočanja iz zraka in neposredne zračne podpore. Pri tem mora biti delovanje te komponente vedno podprto $\mathrm{s}$ kvalificiranimi skupinami za zračno taktično kontrolo. V zračno komponento spadajo 
tudi helikopterji z onemogočanjem iz zraka in bližnjo bojno podporo ter bojna brezpilotna letala. Mornariško komponento v zavezništvu sestavljajo vsi mornariški sistemi za posredne ognje. V vseh treh komponentah sistemi uporabljajo vodene in nevodene izstrelke (AartyP-5(A), 2011, str. 3-1 do 3-3).

$\mathrm{Na}$ prvi pogled je seveda očitno, da so zmogljivosti majhnih oboroženih sil po posameznih komponentah zelo omejene. Doktrina SV navaja, da »/.../ obstajajo naslednje vrste ognjene podpore: artilerijska podpora, minometna podpora, onemogočanje iz zraka in neposredna zračna podpora« (Furlan in drugi, 2006, str. 99). $\mathrm{V}$ resnici imajo vse naštete zmogljivosti na voljo le največje vojske zavezništva. Se pa zmogljivosti vseh teh sistemov pojavljajo v skupnih operacijah zavezništva, v katerih s svojimi zmogljivostmi delujejo tudi najmanjše članice. Doktrina SV celo eksplicitno navaja, da »/.../ vojaška obramba Republike Slovenije temelji na uporabi združenih sil zavezništva, v katerih bodo integrirane sile Slovenske vojske« (Furlan in drugi, 2006, str. 13).

\section{KONCEPT EŠALONIRANJA OGNJEV}

Zavezništvo opredeljuje manever ${ }^{5}$ kot $\gg /$.../ uporabo sil na bojišču s premiki in $\mathrm{V}$ povezavi z ognjem ali ognjenimi delovanji za dosego prednostnega položaja glede na sovražnika v izvedbi naloge« (Brinc in drugi, 2006, str. 148). Vojaška doktrina SV pa manever opredeljuje kot $» / .$. / uporabo sil s premikom v kombinaciji s hitrostjo in ognjeno močjo. Manever je osnovni dejavnik osredotočenja bojne moči na odločilni točki in dejavnik gospodarne uporabe sil in doseganja presenečenja (Furlan in drugi, 2006, str. 96). Preprosteje povedano je manever kombiniranje ognja in premika.

Za ognje, ki zagotavljajo dezintegracijo sovražnika in s tem omogočajo premik, pa je ključno razumevanje koncepta njihovega ešaloniranja. Pojem ešaloniranja, kot je opredeljen v Vojni enciklopediji, se razume kot razporejanje po globini (Gažević, 1971, str. 707). Podrobneje pa koncept opredeljuje doktrina kopenske vojske ZDA. Koncept je relevanten tako $\mathrm{v}$ izvajanju ofenzivnega kot defenzivnega delovanja. Namen ešaloniranja ognjev je vzdrževanje ognja na cilju z optimalnim oborožitvenim sistemom, dokler se lastne sile ne približajo na razdaljo do cilja, ki jo v boju določa tako imenovana razdalja sprejemljivega tveganja (angl. risk estimate distance RED) ${ }^{6}$ za vsak posamezni oborožitveni sistem (FM 3-21.10, 2006, str. 10-21).

Koncept ešaloniranja ognjev zahteva, da se na cilje začne delovati z oborožitvenim sistemom z največjo razdaljo sprejemljivega tveganja. Ko manevrska enota na poti do cilja prečka razdaljo določenega sistema, ogenj tega sistema prekinemo, premaknemo ali prenesemo na drug cilj. To sproži delovanje na cilj s sistemom z naslednjo manjšo razdaljo sprejemljivega tveganja. Čas delovanja po cilju s posameznim sistemom

\footnotetext{
Employment of forces on the battlefield through movement in combination with fire, or fire potential, to achieve a position of advantage in respect to the enemy in order to accomplish the mission.

${ }_{6}$ Pri usposabljanju namesto razdalje sprejemljivega tveganja uporabljamo minimalno varno razdaljo (angl. minimum safety distance-MSD).
} 
je povezan s hitrostjo premika lastnih sil med posameznimi linijami razdalj sprejemljivega tveganja. Proces se nadaljuje do točke, ko oborožitveni sistem z najmanjšo razdaljo sprejemljivega tveganja neha delovati in lastne sile lahko uničijo sovražnika z neposredim ognjem ali so v položaju za izvedbo zaključnega juriša in zavzetje cilja (FM 3-21.10, 2006, str. 10-21).

Za razumevanje koncepta ešaloniranja ognjev je nujno tudi jasno razumevanje pojmov risk estamated distance, minimum safe distance in danger close (bližina lastnih sil). Natančneje te pojme opredeljuje ustrezna zavezniška doktrina, pa tudi publikacija JFIRE (JFIRE, 2012, str. 143-144, 155).

Na kratko pa je razdalja sprejemljivega tveganja tista, ki služi za ešaloniranje ognjev v boju, minimalna varna razdalja ${ }^{7}$ pa v miru med usposabljanjem. Bližina lastnih sil ${ }^{8}$ pa je zgolj opozorilo na povečano tveganje.

\section{EŠALONIRANJE OGNJEV IN SISTEMI OGNJENE PODPORE}

Publikacija JFIRE opredeljuje razdaljo sprejemljivega tveganja in minimalno varno razdaljo za različne sisteme, ki jih uporabljajo v oboroženih silah ZDA, pa tudi v nekaterih drugih članicah Nata. Razdalje, navedene v publikaciji, nam prikazujejo uporabnost koncepta ešaloniranja ognjev. V spodnji tabeli 1 je izvleček teh razdalj za različne oborožitvene sisteme. Nekatere ekvivalente uporabljajo tudi v SV.

Tabela 1:

\begin{tabular}{|l|c|c|c|c|c|}
\hline & & & \multicolumn{2}{|c|}{ RED $(\mathrm{m})$} & \\
\hline oborožitveni sistem & SV & strelivo & stoje & leže & opomba \\
\hline minomet M 224 & M 57 & $60 \mathrm{~mm} \mathrm{HE}$ & 125 & 120 & $2 / 3$ maks. \\
\hline minomet M 252 & $/$ & $81 \mathrm{~mm} \mathrm{HE}$ & 195 & 190 & $2 / 3$ maks. \\
\hline nevodene rakete 70 mm & (PC-9 M) & $70 \mathrm{~mm}$ & 290 & 265 & kontaktni vž. \\
\hline havbica M 119 & $/$ & $105 \mathrm{~mm} \mathrm{HE}$ & 300 & 285 & $2 / 3$ maks. \\
\hline Mk 82 & (PC-9 M) & $500 \mathrm{~kg}$ & 310 & 235 & kontaktni vž. \\
\hline minomet M 120 & MN-9 & $120 \mathrm{~mm} \mathrm{HE}$ & 395 & 365 & $2 / 3$ maks. \\
\hline top-havbica M 109 & TN 90 & $155 \mathrm{~mm} \mathrm{HE}$ & 460 & 440 & $2 / 3$ maks. \\
\hline
\end{tabular}

V praksi pomeni, da se kot minimalne varne razdalje za usposabljanje uporabljajo razdalje, ki jih za posamezne sisteme določijo na posebnem vadišču - v upravi strelišča oziroma vadišča. Le če vadišče/strelišče teh razdalj ne določa, se lahko uporabljajo splošne, kot so zapisane npr. v JFIRE.

8 Razdalja danger close (bližina lastnih sil) za minomete in cevno artilerijo je $600 \mathrm{~m}$, za mornariške topove pa $750 \mathrm{~m}$. Za vse druge sisteme je določena posebej in običajno ustreza 0,1\% PI za stoječo osebo. 
Grafikon 1 kaže, kako pomembna je uporaba različnih sistemov ognjene podpore za delovanje koncepta ešaloniranja ognjev. S konceptom ešaloniranja ognjev in uporabo sistemov različnih zvrsti oziroma rodov manevrsko enoto razmeroma varno pripeljemo na razdaljo 125 metrov do sovražnikovih položajev. Zadnjih 125 metrov je vedno najtežjih in jih je treba premagati s pomočjo neposrednih ognjev in odločnega juriša pehote na nasprotnikove položaje. Če izpustimo enega izmed sistemov ognjene podpore, se nam v konceptu ešaloniranja ognjev pojavi vrzel, ki jo morajo pokriti drugi sistemi ali pa se poveča tveganje izpostavljenosti lastnih sil.

Grafikon 1:

Ešaloniranje ognjev
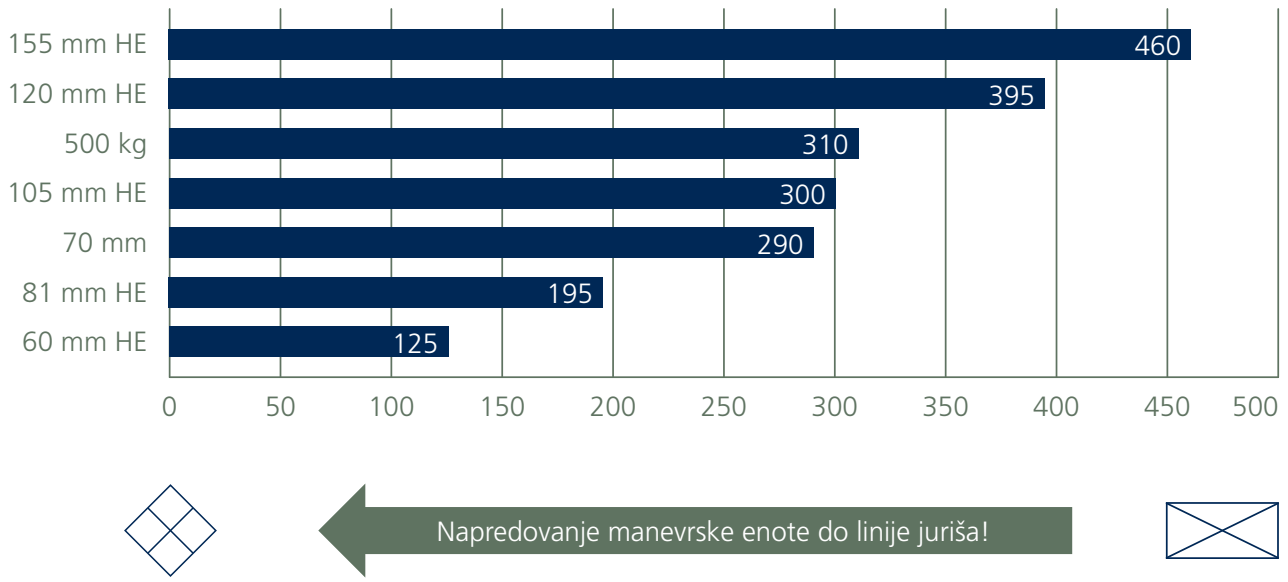

Napredovanje manevrske enote do linije juriša!

Ponazorimo s primerom. Recimo, da je manevrski enoti iz grafikona 1 na voljo le minometna podpora $60 \mathrm{~mm}$ in $120 \mathrm{~mm}$ ter podpora artilerije $155 \mathrm{~mm}$. To pomeni, da ima manevrska enota v približevanju nasprotniku med minometi $120 \mathrm{~mm}$ in $60 \mathrm{~mm}$ 200-metrsko vrzel, ki jo morajo pokriti minometi $60 \mathrm{~mm}$. Za premagovanje 200metrske razdalje bi pehota porabila približno 30 minut $^{9}$. To pomeni dodatnih 750 izstreljenih 60 -milimetrskih minometnih $\min ^{10}$. To so velike številke za raven enote, v kateri so 60-milimetrski minometi, in močno presegajo bojne komplete za takšno oborožitev. To pomeni približno $975 \mathrm{~kg}$ streliva $60 \mathrm{~mm}$, ki bi ga morali nositi vojaki v

\footnotetext{
Izračun temelji na teh predpostavkah: dnevni premik ob dobri vidljivosti, 50 \% vlažnost, 15 stopinj Celzija zračne temperature, 50 stopinj naklona terena. Za te razmere je predvidena hitrost premika 0,1 m/s. Avtor meni, da so te predpostavke ustrezne glede na povprečne letne temperature in vlažnost v Sloveniji. 50-stopinjski naklon pa je bil izbran, ker predstavlja najtežje mogoče razmere na terenu. Hitrosti premikanja v tabeli namreč veljajo za nebojno situacijo oz. fazo premika v zbirni rajon. Ko dodamo dejavnik nevarnosti in stresa, ki se pojavi pri premiku z izhodiščnega na jurišni položaj, se te hitrosti zelo zmanjšajo. To zmanjšanje hitrosti v tabeli najbolje ponazori naklon terena (Hayes, 1996, str. 52).

${ }_{10}$ Za 60-milimetrski minomet, kakršen je M57 v SV, je hitrost streljanja, ki se lahko vzdržuje dlje časa, do 25 min na minuto (Stanimirović, 1973, str 10).
} 
pehotni četi ${ }^{11}$, kakršna je pehotna četa SV brez vozil. Prva alternativa temu je manjša gostota minometnega ognja $\mathrm{v}$ podpori manevru enote, kar pomeni večjo verjetnost izpostavljenosti sovražnikovemu ognju. Druga možnost pa je uporaba ognjev drugih sistemov, kot so minometi $81 \mathrm{~mm}$ ter ognji letalskih in mornariških sil.

Poveljujoči seveda nikoli nima na voljo dovolj streliva, da bi zadostil teoretičnim potrebam v podpori manevru, zato se bo morala enota zanašati na njegovo sposobnost presoje tveganja in racionalne uporabe sredstev. Z zgornjim primerom poskušamo zgolj ponazoriti, kako se težave množijo, če izpuščamo oborožitvene sisteme pri ešaloniranju ognjev.

Če zdaj prek koncepta ešaloniranja ognjev pogledamo formacije enot na ravni brigade $\mathrm{v}$ treh vojskah, ki so reference za vse druge, ugotovimo, da ima ameriška pehotna brigada na ravni brigade bataljon havbic $105 \mathrm{~mm}$ (16 cevi), na ravni pehotnega bataljona pa $\mathrm{v}$ minometnem vodu po štiri minomete $120 \mathrm{~mm}$ in štiri minomete $81 \mathrm{~mm}$, na ravni pehotne čete pa najdemo dva minometa $60 \mathrm{~mm}$ (FKSM, 2010, str. B-21, B-23, B-35). Brigada Stryker ima v artilerijskem bataljonu na ravni brigade 12 havbic $155 \mathrm{~mm}$. Na ravni bataljona Stryker pa ima štiri minomete $81 \mathrm{~mm}$ in na ravni čete dva minometa $60 \mathrm{~mm}$ (FKSM, 2010, str. C-16, C-18, C-29).

Britanci so nekoliko bolj prilagodljivi in artilerijo na ravni brigade kombinirajo skladno s potrebami. Običajno jo predstavlja osem 105-milimetrskih ali 155-milimetrskih topov/havbic, organiziranih $\mathrm{v}$ artilerijski bataljon ${ }^{12}$. Na ravni bataljonov imajo minometne vode $\mathrm{s}$ po šestimi 81 -milimetrskimi minometi in na ravni čete po tri 60-milimetrske minomete (The British Army, 2015).

Brigade oboroženih sil Ruske federacije poznajo artilerijske bataljone s sistemi kalibra $152 \mathrm{~mm}$ in bataljone raketne artilerije. Na ravni bataljonov pa imajo minometne čete, v katerih kombinirajo minomete $120 \mathrm{~mm}$ (8 orožij) ali $82 \mathrm{~mm}$ (8 orožij). Na ravni pehotne čete poznajo 60-milimetrske minomete (Ortman, 2015).

Priloge 4, 5 in 6 grafično prikazujejo organiziranost minometnih in artilerijskih sistemov v prej omenjenih oboroženih silah, vendar smo jih za članek omejili na dva manevrska elementa v brigadi, da bi lažje primerjali stanje v SV. Treba je vedeti, da ima sodobna brigada tri do pet manevrskih elementov v rangu bataljona, od katerih je vsaj en izvidniški.

Vse omenjene vojske predpostavljajo vsaj lokalno prevlado $\mathrm{v}$ zraku, tako da bi bile manevrskim enotam na bojišču na voljo tudi zmogljivosti neposredne zračne podpore in ob delovanju v priobalnem pasu tudi zmogljivosti mornariških ognjev.

\footnotetext{
${ }^{I I}$ MM 60 mm je četno orožje, kar pomeni da se njegovo breme lahko razporedi na vse vojake v četi. Če ima četa pribl. 110 pripadnikov, ki lahko nosijo dodatno breme, to pomeni dodatnih $9 \mathrm{~kg}$ na posameznika.

${ }_{12}$ Brigadna artilerijska skupina ima lahko na voljo tudi MLRS-sisteme. Zanimiva je opazka, da so OS Hrvaške pred kratkim objavile namero pridobiti iz ZDA 16 MLRS-sistemov.
} 
Sem lahko štejemo tudi zmogljivosti manevrirnih raket in raketne artilerije, za katero razdalje več sto kilometrov navadno ne pomenijo ovir.

Za koncept ešaloniranja ognjev je skoraj nepomembno, ali govorimo o ubojnih ali neubojnih učinkih. Gre za to, da sovražniku preprečimo delovanje na naše sile, kar pomeni, da ne gre nujno za ubojne učinke. Če z delovanjem elementov vplivanja, kot so operacije civilno-vojaškega delovanja, psihološke operacije in informacijske operacije, lahko zagotovimo varnost lastnega manevra, to lahko razumemo v smislu koncepta ešaloniranja ognjev. Za racionalno uporabo razpoložljivih virov je pri ešaloniranju ognjev nujno upoštevati vse elemente združene ognjene podpore, kar dosežemo z izbiro ciljev in delovanjem nanje (angl. targeting).

\section{SLOVENSKA VOJSKA IN EŠALONIRANJE OGNJEV}

Kot je bilo že ugotovljeno, je bila SV med letoma 2001 in 2015 na taktični ravni brez sistemov za posredni ogenj, manjših od $120 \mathrm{~mm}$. Kot je prikazano v tabeli in grafikonu 1, to pomeni, da se je ešaloniranje ognjev s sistemi za posredni ogenj končalo 395 metrov od cilja, kar pomeni 270 metrov izpostavljenosti ${ }^{13}$ oziroma $\mathrm{v}$ fazi približevanja cilju več kot dodatne pol ure izpostavljenosti sovražnikovemu ognju. Tega ne more nadomestiti nobena zaščitna oprema posameznika ali oklepna zaščita vozila. Pol ure in več izpostavljenosti organiziranemu in discipliniranemu sovražniku pomeni skoraj gotovo smrt.

Uspeh na sodobnem bojišču zahteva učinkovito ravnotežje med ognjem in manevrom. Zanemarjanje enega na račun drugega povzroča, da je prvi ranljiv zaradi učinkov drugega (Johnson, 2000, str. 26). S transformacijo leta 2013 in ponovnim uvajanjem minometov $60 \mathrm{~mm}$ v pehotne čete je SV pridobila na sposobnosti ešaloniranja ognjev (glej prilogo 1). Treba pa je opozoriti na zmoto, ki je dolgo veljala, ne le v SV, temveč tudi v razpravah zunaj nje. Zmota je, da minomete $60 \mathrm{~mm}$ kot orožje za ognjeno podporo na najnižji taktični ravni lahko nadomestimo s sodobnimi avtomatskimi bombometi. Tega niso storili v nobeni pomembnejših oboroženih sil, vzrokov za to je več. Avtomatski bombometi so predvsem orožje za neposredno ognjeno delovanje, minometi pa za posredno. Avtomatski bombometi so okornejši in izkrcana pehota ${ }^{14}$ jih težje prenaša, njihovo strelivo ima manjši polmer onesposabljanja žive sile, zato je manj primerno za onemogočanje sovražnika, in ne nazadnje je krivulja leta granate bombometa položnejša ${ }^{15}$ ter zato manj primerna za delovanje na sovražnika v zaklonu ali za vertikalno oviro (Žabkar, 2007, str. 210 2014). To pa ne pomeni, da avtomatski bombometi nimajo svoje vloge na bojišču. Namen tega članka ni problematizirati uporabnosti avtomatskih bombometov kot

\footnotetext{
${ }^{13}$ Kot že rečeno, je zadnjih 125 m do cilja v napadu oz. ko se sovražnik približa na 125 m do naših obrambnih linij to v vsakem primeru prostor, ki ga je treba pokrivati s sistemi za neposredno delovanje.

${ }^{14}$ So pa odlični, ko so nameščeni na vozila.

15 Seveda je tu govora o merjenem delovanju na cilj.
} 
nadomestka za minomete $60 \mathrm{~mm}$, za zdaj naj zadostuje, da se avtomatski bombometi in minometi na bojišču dopolnjujejo, vsak sistem ima na njem svojo vlogo.

Če torej nadaljujemo, je danes v pehotni četi SV vod za ognjeno podporo z dvema minometoma $60 \mathrm{~mm}$ (Pišlar, 2015, str. 21), na brigadni ravni pa ima SV baterijo za ognjeno podporo, v kateri kombinira topove/havbice $155 \mathrm{~mm}$ in minomete $120 \mathrm{~mm}^{16}$ (Pišlar, 2014, str. 16). Na ravni baterije za ognjeno podporo je do osem minometov MN-9 $120 \mathrm{~mm}$ in do šest topov/havbic TN90 $155 \mathrm{~mm} .{ }^{17}$ Popolnjenost materialno-tehničnih sredstev in usposobljenost baterije za ognjeno podporo pa je slaba ${ }^{18}$. Avtorjeva ocena temelji na javno dostopnih podatkih o težavah s kadrovsko popolnjenostjo celotne SV, s pomanjkanjem finančnih sredstev za posodabljanje opreme, načrtovanih v SOPR, in izjav predsednika republike ter ministrov za obrambo v zadnjih petih letih.

Tu je treba opozoriti tudi na nesprejemljivost stališča, po katerem je mogoče havbice $105 \mathrm{~mm}$ nadomestiti z uporabo minometov $120 \mathrm{~mm}$. Kot pri vprašanjih, ali avtomatski bombomet ali minomet $60 \mathrm{~mm}$, gre tudi tu za dva oborožitvena sistema, ki imata na bojišču svojo posebno vlogo. Kljub temu da sodobni samovozni 120-milimetrski minometi dosegajo približno enake razdalje kot 105-milimetrske havbice, gre za bistveno razliko v namenu orožja. Minometi $120 \mathrm{~mm}$ ostajajo v vseh vojskah orožje, ki je na voljo poveljniku manevrskega elementa na ravni bataljona in je s svojo prilagodljivostjo ter odzivnostjo tam tudi najbolj uporabno. Havbice $105 \mathrm{~mm}$ pa ostajajo oborožitveni sistem, ki je na voljo poveljniku brigadne ravni za oblikovanje razmer na bojišču, skladno z njegovimi potrebami. Z vidika potrebe po ešaloniranju ognjev pa je nujnost obeh sistemov v formacijah povsem jasno opredeljena zgoraj.

SV ima v 15. polku vojaškega letalstva šolska bojna letala PC-9M, na katerih lahko kombinira različno oborožitev, od letalskih bomb Mk 81 in Mk 82 prek lanserjev nevodenih raket $70 \mathrm{~mm}$ do mitraljeza $12,7 \mathrm{~mm}$ (Slovenska vojska, http://www.slovenskavojska.si/).

Za sprejemanje zmogljivosti ognjev zavezništva ima SV v bateriji za ognjeno podporo, pa tudi v 15. polku vojaškega letalstva, usposobljene usmerjevalce združenih ognjev, ki so usposobljeni za usmerjanje različnih zavezniških oborožitvenih sistemov, tako letalskih kot helikopterskih, artilerijskih, minometnih in mornariških. SV je na področju usmerjanja združenih ognjev prevzela regionalno pobudo in začela ustanavljati regionalno šolo za te zmogljivosti (Oblak, 2015, str. 19).

\footnotetext{
${ }^{16}$ Edina podobna rešitev $v$ Natu, poznana avtorju, je francoska, pri kateri ravno tako $v$ artilerijskih enotah kombinirajo minometne $120 \mathrm{~mm}$ in artilerijske sisteme, a z jasno opredelitvijo, da je to storjeno zaradi usposabljanja in logistike. Minometi so sicer eksplicitno namenjeni pehotnim enotam (Armee de Terre, 2015, http//:www). V bojih so lastnice minometov $120 \mathrm{~mm}$ pehotne enote ranga bataljonov, artilerija pa je prisotna na ravni brigade in višje.

${ }^{17}$ Gre za domnevo. Številke so okvirne in so pridobljene na podlagi avtorjevih analiz razpoložljivih virov (predvsem revije SV). Uradni podatki o številu sistemov v enotah so namreč zaupni.

18 Gre za osebno oceno avtorja in ne uradno stališče pristojnih v SV. Mnenja pristojnih so izražena v različnih poročilih in zapisnikih analiz, ki sicer niso zaupne narave, a jih zaradi osebne prizadetosti posameznikov $v$ članku ne uporabljamo.
} 
V pehotnih enotah naj bi SV v obdobju od 2013 do 2018 oblikovala tudi zmogljivosti za civilno-vojaško sodelovanje, za potrebe bataljonske bojne skupine pa tudi modul za psihološko delovanje (SOPR, 2013, str. 14).

Po letu 2013 SV ponovno dobiva zmogljivosti za ešaloniranje ognjev, dejstvo pa je, da pri tem v organizacijskem smislu še vedno ostajajo precejšnje vrzeli, predvsem v minometni podpori, pa tudi podpori 105-milimetrskih havbic. Nekaterih zmogljivosti SV ne bo imela, saj presegajo njene okvire, marsikatero zmogljivost v ešaloniranju ognjev pa si bo lahko zagotovila tudi z delitvijo zavezniških zmogljivosti.

Ne moremo pa oceniti učinkovitosti sedanjih zmogljivosti sistemov ognjene podpore, saj SV zanje nima razvitih nikakršnih kazalnikov ${ }^{19}$. Tako ne moremo ne potrditi ne ovreči domneve, da je njena učinkovitost omejena in da enote niso dovolj usposobljene za uporabo sistemov ognjene podpore v konceptu združenega bojevanja rodov. Že našteta dejstva kažejo na to, da ima SV pri zagotavljanju učinkovite ognjene podpore še velike težave. Nimamo razloga, da bi domnevali drugače.

\section{UGOTOVITVE, POMEMBNE ZA SV}

Ko govorimo o zagotavljanju zaščite in varnosti vojaka na sodobnem bojišču, prevečkrat prevladuje mnenje, da ju dosežemo z boljšo individualno zaščito (uniforme, čelade, neprebojni jopiči) in oklepno zaščitenimi transportnimi sredstvi. Tudi če imajo ti sistemi pomembno vlogo, skladno s tipom operacije, v kateri so manevrske enote, pa ostaja dejstvo, da je največja stopnja varnosti za vojaka na manevrskem bojišču dosežena tako, da sovražnik nanj ne more delovati, kar na manevrskem bojišču dosežemo z uporabo sistemov ognjene podpore s konceptom ešaloniranja ognjev.

V Natu imajo vodilne države na voljo precejšnje zmogljivosti združene ognjene podpore, ki vse močno presegajo zmogljivosti, ki jih ima SV. SV tako v Natovih operacijah računa na to, da bo imela na voljo tudi zmogljivosti združene ognjene podpore iz drugih držav članic. Pri tem pa mora poskrbeti, da bo sposobna sprejemati učinke teh sistemov, pri čemer ima bistveno vlogo ustrezno usposobljen kader predvsem pripadniki enot za usmerjanje združenih ognjev in enot artilerijskih izvidnikov.

Nato je jasen v tem, da mora vsaka država članica najprej sama poskrbeti za svojo varnost in razvijati zmogljivosti zanjo (The North Atlantic Treaty, 1949). Kot je ugotovil Johnson v svoji študiji leta 2000, je treba zagotoviti dovolj sistemov za ognjeno podporo in na čim nižji taktični ravni. Ker je skladno z doktrino zavezništva

\footnotetext{
${ }^{19}$ Kot zanimivost lahko navedemo podatke za kopensko vojsko ZDA, ki je s kazalniki, ki jih uporabljajo v njihovih NTC (National Training Center - naša verzija se imenuje CBU), ugotovila, da so enote v NTC leta 1987 dosegale 60-odstotno učinkovitost ognjenih nalog, leta 2001 pa samo še 12-odstotno. Ti kazalniki so bili skrb vzbujajoči in vojska se je lotila temeljite analize vzrokov. Johnson v svoji študiji izpostavlja predvsem vprašanje neustrezne digitalizacije procesov (Johnson, 2000, str. 27 in 34-36).
} 
vod najnižja taktična raven, od katere se pričakuje samostojno izvajanje nalog, menimo, da mora SV na ravni voda zagotoviti minomete $60 \mathrm{~mm}$. Graditi mora sistem ognjev od ravni voda navzgor. Vod je tista taktična enota, ki lahko že samostojno opravlja nekatere naloge oziroma zavzema cilje na bojišču. $\mathrm{V}$ ta namen mora imeti poveljnik voda na voljo tudi ustrezne sisteme za posredno delovanje, kar so minometi $60 \mathrm{~mm}$. Ti bi omogočali poveljniku voda, da bi svoje oddelke lahko razmeroma varno pripeljal v položaj za odločilni juriš na objekt ali v položaj, iz katerega bi z ognjem iz orožja za neposredno delovanje lahko uničili sovražnika. SV bi morala na raven čete uvesti tudi minometne oddelke z minometi $81 \mathrm{~mm}$ (dve orožji) in ponovno tudi minometne vode z minometi $120 \mathrm{~mm}$ oziroma tako imenovane čete za ognjeno podporo na ravni polka. Minometni sistemi so po našem mnenju bistveni za uspeh manevra $\mathrm{SV}^{20}$. Uvedba minometov v obliki minometnih oddelkov (dve orožji) na raven voda in čete seveda pomeni precejšen izziv, tako materialni kot kadrovski in voditeljski. Izziv bi bil tudi zagotoviti ustrezno količino streliva na vodni ravni, predvsem pa njegovega transporta. Prav tako bi morali v sistemu izobraževanja častnikov na vstopni ravni šole za častnike zagotoviti razumevanje uporabe minometov na vodni ravni. Toda prednosti minometov na vodni in četni ravni bi odtehtale izzive.

Oborožene sile ZDA, Velike Britanije in Ruske federacije ne poznajo minometnih sistemov na ravni voda, toda na tej ravni lahko zagotavljajo ognje tudi z uporabo različnih zračnih, kopenskih in mornariških sistemov. In ko govorimo o njih, govorimo o bojnih helikopterjih, jurišnih letalih, manevrirnih raketah, vodenih artilerijskih in minometnih izstrelkih. Vseh teh pa SV nima in jih še nekaj časa ob sedanjih finančnih perspektivah ne bo imela.

Seveda predlagana rešitev (glej prilogo 2) pomeni izziv. Vztrajamo pa, da je $\mathrm{v}$ manevrskih enotah treba zagotoviti vse tri tipe minometov $(60 \mathrm{~mm}, 81 \mathrm{~mm}$ in $120 \mathrm{~mm}$ ), ker je potreba po njih jasno izražena. Mogoče so tudi druge rešitve, ki trenutno najbrž ne bi pomenile tolikšnega izziva (priloga 3). Minomete $60 \mathrm{~mm}$ bi lahko zadržali na četni ravni in njihovo število povečali na tri orožja v oddelku. Mogoča bi bila tudi kombinacija minometov $60 \mathrm{~mm}$ in $81 \mathrm{~mm}$ na četni ravni $\mathrm{v}$ večjem vodu za ognjeno podporo, ali pa kombinacija minometov $81 \mathrm{~mm}$ in $120 \mathrm{~mm}$ na polkovni ravni $\mathrm{v}$ tako imenovani četi za ognjeno podporo. Na polkovni ravni je pri minometih mogočih več rešitev. Prva je dvojna oborožitev v teh enotah, druga je enota minometov $81 \mathrm{~mm}$ in enota minometov $120 \mathrm{~mm}$, mogoča pa je tudi rešitev s tako imenovanimi vložnimi cevmi, s katerimi iz minometov $120 \mathrm{~mm}$ s posebnimi prilagoditvami lahko streljamo tudi mine kalibra $81 \mathrm{~mm}^{21}$ (Jones, 2008, str. 585 in 587). Minometov je na ravni polka težko preveč, je pa zaradi dovoljenih režimov ognja in maksimalne dovoljene obremenitve na posamezno orožje minimalna enota vod - torej štiri orožja. Sodobne vojske poznajo tudi rešitve s šestimi in osmimi

\footnotetext{
${ }^{20}$ Govorimo o delovanju SV zunaj zavezništva. Vsaka članica je najprej sama odgovorna za svojo varnost. Ko bodo enote SV delovale v formacijah zavezništva, seveda lahko računajo na zavezniške sisteme ZOGP.

${ }^{21}$ Gre za minomete ki jih uporablja kopenska vojska ZDA. Vložne cevi uporabljajo za usposabljanje zaradi viškov streliva $81 \mathrm{~mm}$.
} 
orožji v enotah bataljonske ravni. Pred transformacijo smo v SV poznali minometne čete na ravni bataljona s po dvema ognjenima vodoma, opremljenima z orožji kalibra $120 \mathrm{~mm}$ - skupaj osem orožij.

Minometni sistemi morajo biti pod nadzorom manevrskega poveljnika, to je najmanj poveljnika čete in polka, saj samo to zagotavlja njihovo razpoložljivost, ko jih manevrska enota potrebuje. Za uspeh koncepta ešaloniranja ognjev je ključna integracija minometnih sistemov $\mathrm{z}$ manevrsko enoto, ki jo zagotavljajo skupno usposabljanje ter učinkovito vodenje in upravljanje.

Na prvi pogled se sicer zdi, da bi lahko katerega izmed teh sistemov tudi izpustili in bi to vrzel pokrili z drugimi sistemi, $v$ resnici pa, kot smo pokazali zgoraj, to z vidika varnosti ni sprejemljivo. Zaradi količine in teže streliva minometnih sistemov pa je treba enote najnižje taktične ravni (čete in polki) opremiti z ustreznimi transportnimi sredstvi. To velja za manevrske enote lahke oziroma motorizirane pehote ${ }^{22}$, zračnodesantne in zračno-jurišne pehote, saj se pehota bojuje pretežno izkrcano.

Nekoliko drugače velja za enote gorske in oklepno-mehanizirane pehote ${ }^{23}$. Pri slednjih se taktične naloge rešujejo pretežno z vozili, pehota pa služi predvsem za zaščito teh vozil. Vozila oklepno-mehanizirane pehote imajo sisteme ognjene podpore za neposredno delovanje in stopnjo mobilnosti, ki jim omogoča večjo hitrost premika in ognjeno delovanje na večjih razdaljah. Poleg tega njihov temeljni način delovanja ni z izkrcano pehoto, ampak taktične naloge rešujejo predvsem z vozili. Zato potreba po podpori 60-milimetrskih minometov ni tako velika, potrebujejo pa več ognjene podpore sistemov za posredni ogenj večjega kalibra $\mathrm{z}$ daljšim dometom in boljšo mobilnostjo, torej samovozne sisteme (kolesne ali gosenične, odvisno od osnovnega tipa vozila). Po drugi strani je gorski polk manj gibljiv, transport v gorskem okolju je zelo omejen. Hkrati pa je gorski teren poseben bojni multiplikator za orožje ognjene podpore (Kuhar, 2008, str. 48). Tako je količino in kaliber orožja za posredne ognje v gorski enoti primerno omejiti na dva minometa $60 \mathrm{~mm}$ v četi in minomete $81 \mathrm{~mm}$ na ravni polka. Kar sicer ne pomeni, da so minometi $120 \mathrm{~mm}$ v gorski enoti neuporabni, a je treba prej ustrezno rešiti transport orožja in streliva.

Z vidika ešaloniranja ognjev je treba zagotoviti tudi več artilerije na ravni brigade. Ena baterija topov/havbic $155 \mathrm{~mm}$ lahko podpira en sam polk. Zato je treba zagotoviti vsaj dve bateriji z minimalno šestimi orožji na baterijo. Za SV pomeni

\footnotetext{
${ }^{22}$ Zavezništvo sicer pojma lahka pehota v svoji klasifikaciji različnih tipov pehote ne pozna. Pozna samo motorizirano pehoto, ki se bojuje pretežno v izkrcnem načinu, opremljena pa je z vozili, ki ji dajejo določeno stopnjo zaščite, mobilnosti in ognjene moči. Polki SV ne spadajo v to kategorijo pehote, saj v svoji sestavi nimajo ustreznih vozil, zato bi bila zanje še najustreznejša oznaka lahka pehota, za katero se domneva, da je zelo omejeno mobilna (noge vojakov) in nima oklepne zaščite vozil (če že ima vozila, so to tovornjaki ali neoklepna transportna vozila $4 \times 4$ ).

${ }^{23}$ SV ima kot enoto za gorsko bojevanje 132. pehotni polk, nima pa polka v vlogi mehanizirane enote. Pred transformacijo je bila ta vloga predvidena za 74. MOTB, zdaj pa je 72. brigada ( $v$ njeni sestavi je tudi 74 pehotni polk) nosilka oblikovanja zmogljivosti srednje bataljonske bojne skupine, ki naj bi bila zametek prihodnje mehanizirane bataljonske bojne skupne.
} 
artilerija brigadne ravni tudi najvišjo stopnjo artilerijske podpore, nad njo nima in ne bo imela zmogljivosti zagotavljanja artilerijskih ognjev. Predvsem je artilerija na brigadni ravni v SV tako imenovani fire provider, medtem ko so polki oziroma bataljonske bojne skupine uporabniki teh ognjev. Zato je treba razmisliti o čim močnejših zmogljivostih na tej ravni, morda celo z dvojno (105 mm in $155 \mathrm{~mm}$ ) oborožitvijo v baterijah, saj bodo te zmogljivosti zagotavljale ognje za vso SV tudi ob aktiviranju vojaške strateške rezerve. Z dvojno oborožitvijo bi pri oblikovanju razmer na bojišču poveljniku brigade omogočali večjo prilagodljivost njegovih manevrskih elementov, hkrati pa bi lahko ob aktiviranju vojaške strateške rezerve iz enega artilerijskega bataljona ustvarili dva. Predvsem pa ne smemo dovoliti, da bi artilerija postala sama sebi namen. ${ }^{24}$ Njena vloga mora biti najprej osredotočena na bližnjo ognjeno podporo manevrskim enotam in šele drugotno na zagotavljanje ognjev po globini. Transformacija leta 2012 je brigadam na taktični ravni dodelila artilerijske enote, ki jih poveljniki tudi vključujejo v usposabljanje manevrskih enot. Učinkovitost te integracije pa, kot že rečeno, ostaja vprašljiva.

Kombiniranje orožij 105 mm in 155 mm (po možnosti samovoznih na kolesnih vozilih) bi sicer povzročilo nekaj dodatnega logističnega bremena za enoto, toda $\mathrm{z}$ vidika ešaloniranja ognjev bi bila odločitev povsem smiselna. Navsezadnje zdaj v bateriji za ognjeno podporo združujemo minomete $120 \mathrm{~mm}$ in topove/havbice $155 \mathrm{~mm}$, tako da v smislu logističnega bremena zaradi streliva velikih razlik ne bi bilo.

V artilerijskih izvidniških enotah je treba zagotoviti usposobljeno moštvo, ki bo usklajevalo ognjeno podporo poveljnikom manevrskih enot in bo vodilo minometne in artilerijske ognje na cilje. Artilerijske izvidnike je treba usposobiti do ravni opazovalcev posredne ognjene podpore (angl. JFO) ${ }^{25}$, da bi lahko sodelovali v sistemu združene ognjene podpore SV in Nata. Artilerijski izvidniki na ravni opazovalcev posredne ognjene podpore bi tudi okrepili delo usmerjevalcev združenih ognjev. $\mathrm{V}$ ta namen bi bilo treba razširiti vlogo in naloge šole za usmerjevalce združenih ognjev v SV.

Te zahteve seveda pomenijo povečanje moštva v enotah s sistemi za ognjeno podporo. Po našem mnenju bi to lahko storili, saj rezerve v formacijah SV so. Priloga 3 je avtorjev predlog, za katerega je menja, da je trenutno uresničljiv ob predpostavki, da je pristop k spremembam formacij SV celovit. Dolgoročni cilj pa bi moral ostati tak, kot je zapisan v prilogi 2.

Alternativa minometnim in artilerijskih sistemom ognjene podpore je, da vrzel pokrivajo drugi sistemi ognjene podpore, pretežno letala in helikopterji z ustrezno oborožitvijo. Teh pa SV nima in jih z razvojnimi dokumenti niti ne predvideva.

\footnotetext{
${ }^{24}$ Na to je na primeru kopenske vojske ZDA opozoril tudi Johnson v svoji študiji, v kateri je ugotovil, da artileristi zavračajo vlogo »podpore kupca« in so precej raje »za volanom» (Johnson, 2000, str. 30).

${ }_{25}$ JFO = Joint Forward Observer ... v Natu označuje specialiste za usmerjanje predvsem artilerijskih in sekundarno tudi drugih sistemov ZOGP. Njihov status ni enak usmerjevalcem združenih ognjev, lahko pa dopolnjujejo njihovo delo in s tem bistveno pripomorejo $k$ njihovi učinkovitosti.
} 
PC-9M je šolsko bojno letalo z odličnimi karakteristikami in primerno oborožitvijo, a je bojno uporabno le v zelo omejenem obsegu in v situacijah, ko zračne grožnje ni in je grožnja sistemov zračne obrambe minimalna (Peacock, 2012, str. 430). To so samo protiuporniške operacije, kakršne poznamo iz Afganistana. Je pa seveda PC-9M odlično letalo za usposabljanje za uporabo združene ognjene podpore in ešaloniranje ognjev.

Za delovanje koncepta ešaloniranja ognjev je absolutno nujna tudi vzpostavitev ustreznega sistema vodenja in upravljanja sistemov ognjene podpore oziroma »združene« ognjene podpore. Ti sistemi so danes digitalizirani, kar omogoča večjo odzivnost in načeloma zmanjšuje potrebo po moštvu. Vendar pa se je digitalizacije sistema upravljanja in vodenja sistemov ognjene podpore treba lotiti zelo previdno. $\mathrm{Na}$ pasti digitalizacije je zelo nazorno opozoril podpolkovnik ameriške kopenske vojske Johnson, R. C., ki je ugotovil, da je digitalizacija sistema vodenja in upravljanja pravzaprav zmanjšala učinkovitost artilerijskih enot pri zagotavljanju bližnje podpore manevrskim enotam. Digitalizacija je namreč povzročila centralizacijo odločanja in mikromenedžment, namesto da bi omogočila decentralizacijo in prepuščala pobudo podrejenim in tako povečala odzivnost tam, kjer je najbolj potrebna - v bližinskem boju (Johnson, 2000, str. 34-36).

Tudi elementi vplivanja imajo svojo vlogo pri ešaloniranju ognjev za manevrske enote SV. Odvisno od tipa operacije lahko elementi civilno-vojaškega in psihološkega delovanja ter drugi različno učinkovito vplivajo na sovražnika in tako zmanjšajo izpostavljenost pripadnikov SV njegovemu ognju. SV mora razmisliti o vzpostavitvi formacijskih enot za elemente vplivanja, predvsem civilno-vojaškega in psihološkega delovanja.

Med ključnimi nalogami za delovanje ešaloniranja ognjev, ki SV še čakajo, pa sta sprejetje ustreznih doktrinarnih in pravnoformalnih podlag ter organizacija ustreznega usposabljanja enot in predvsem poveljujočega kadra. Za delovanje koncepta ešaloniranja ognjev je nujno razumevanje razdalje sprejemljivega tveganja, minimalne varne razdalje in bližine lastnih sil ter teorije, ki je za njimi. Stanag 7144 je v veljavi v SV, a poleg razlage pojmov razdalja sprejemljivega tveganja in bližina lastnih sil ter navedbe nekaj primerov razdalj ne vsebuje nekaterih drugih pomembnih informacij za delovanje koncepta ešaloniranja ognjev. Predvsem manjkajo definicije in opredelitve minimalnih varnih razdalj za posamezne oborožitvene sisteme. ${ }^{26}$ To je tudi razumljivo, saj Stanagi pomenijo minimalni dogovorjeni skupni standard. Stvar posamezne članice pa je, da podrobneje opredeli strokovno-tehnične podrobnosti skladno s skupnimi standardi, svojimi potrebami in omejitvami. SV ima pri tem dve možnosti. Prva je, da razvije svojo metodologijo določanja teh razdalj in jih uvede v uporabo. Druga pa je, da se ozre po dostopnih publikacijah zaveznic, ki obravnavajo sisteme $\mathrm{z}$ enakimi ali podobnimi značilnostmi in jih formalno uvede $\mathrm{v}$ uporabo $\mathrm{v} \mathrm{SV}$. Po avtorjevem mnenju je JFIRE publikacija (ALSA-center), ki bi povsem zadoščala

${ }^{26}$ Minimalne varne razdalje so nujne za usposabljanje z ostrim strelivom $v$ SV. 
$\mathrm{SV}$, tako pri samostojnem delovanju kot pri delovanju v zavezništvu. Z aktom ministra bi tako publikacijo lahko uvedli v uporabo v SV, skupaj z morebitnimi strokovnimi pripombami ali omejitvami pri njeni uporabi. To je nujno tudi zaradi pravne varnosti poveljujočih in pripadnikov, ki načrtujejo in izvajajo ognje v podpori manevru enot SV.

Najpomembnejša za razumevanje delovanja koncepta ešaloniranja ognjev in sistemov za posredni ogenj v združeni ognjeni podpori SV in Nata pa sta izobraževanje in usposabljanje. Ešaloniranje ognjev je treba najprej poučevati na vseh častniških šolah nad ravnjo voda in na vseh podčastniških šolah nad ravnjo četnega podčastnika. SV tudi že izvaja mednarodno uveljavljeno vajo Adriatic Strike, ki je namenjena predvsem usmerjevalcem združenih ognjev. S tem je dokazala, da je vaja lahko odlična priložnost za usposabljanje manevrskih elementov iz uporabe sistemov ognjene podpore (tako SV kot zavezniške).

Vsekakor pa mora pravilno ešaloniranje razpoložljivih ognjev v podpori manevru postati v SV pogoj za pozitivno oceno izvedbe katere koli taktične vaje z bojnim streljanjem nad ravnjo oddelka.

\section{Literatura}

1. ATTP 3-21.90, 2011. Tactical Employment of Mortars. HQ, Department of the Army, Washington, $D C$.

2. Brinc in drugi, 2006. Angleško-slovenski vojaški terminološki slovar. PDRIU http://intra. mors.si/index.php?id=1718 (13. 6. 2015).

3. Državni zbor Republike Slovenije, 2004. Zakon o obrambi (uradno prečiščeno besedilo) (ZObr-UPB1). Ljubljana.

4. FKSM 71-8, 2010. Armor/Cavalry reference data; Brigade combat teams. US Army Armor Center, Fort Knox, KY.

5. FM 3-21.10, 2006. The Infantry Company. Headquarters Department of the Army, Washington, $D C$.

6. Furlan, B. (in drugi), 2006. Vojaška doktrina. Ljubljana: Defensor, d. o. o.

7. Gažević, N., in drugi, 1971. Vojna enciklopedija (drugo izdanje) - 2 Brdo-Foa. Izdanje redakcije vojne enciklopedije, Beograd.

8. Gažević, N., in drugi, 1973. Vojna enciklopedija (drugo izdanje) - 6 Nauloh-Podvodni. Izdanje redakcije vojne enciklopedije, Beograd.

9. Gažević, N., in drugi, 1975. Vojna enciklopedija (drugo izdanje) - 10 Tirani-Žužul. Izdanje redakcije vojne enciklopedije, Beograd.

10. Garb in drugi, 2009. Razlagalni vojaški slovar. http://intra.mors.si/index.php?id=1718 (13. 6. 2015).

11. Hacket, J., 2015. The Military balance; the annual assessment of global military capabilities and defence economics 2015. The International Institute for Strategic Studies, London, UK.

12. Hayes, T. R., 1996. Dismounted Infantry Movement Rate Study. Simulation Technologies, Inc., Dayton, Ohio.

13. JFIRE, 2012. Multi-service tactics, tehniques, and procedures for the joint application of firepower. Air Land Sea Aplication Center, ZDA.

14. Jones, R. D., in Leland, N., 2008. Jane's Infantry Weapons 2008-2009. Biddles Ltd., Kings Lynn, Great Britan. 
15. Johnson, R. C., 2000. Fighting with fires: Decentralised Control to Increase Responsivness. School of Advanced Military Studies, USA CGSC, Forth Leavenworth, Kansas.

16. Kolednik, A., 2015. Zakaj hočejo Hrvati imeti raketometes 300-kilometrskim dosegom? (video). Planet Siol.net http://www.siol.net/novice/svet/2015/10/hrvaska_zeli_imeti_ raketomete.aspx (13. 10. 2015).

17. Kuhar, M., 2008. Taktika bojevanja v gorah-priročnik. MORS, Ljubljana, 2008.

18. NATO, 2013. AAP-06 Edition 2013, NATO glossary of terms and definitions (English and French). NATO Stardandisation Agency.

19. NATO, 2011. AartyP-5(A) Nato Indirect Fire Systems Tactical Doctrine. NATO Stardandisation Agency.

20. Osterman, A., 2015. Koncept Združene Ognjene Podpore SV. GŠSV, Ljubljana.

21. Oblak, N., 2015. Šola za usmerjevalce združenega ognja. Revija SV, 5. maj 2015. Ljubljana: $M O R S$.

22. Oblak, N., 2015. Adriatic Strike 2015. Revija SV, 6. junij 2015. Ljubljana: MO RS.

23. Peacock, L., in von Rosenback, A., 2012. IHS Jane's World Air forces 2012 - issue thrtiyfive. IHS Global Limited, UK.

24. Pišlar, M., 2015. Artilerija 72. Brigade na usposabljanju za vojaško evidenčne dolžnosti. Revija SV, 1. januar 2014. Ljubljana: MO RS

25. Pišlar, M., 2015. SV bogatejša za 46 artilercev. Revija SV, 12. december 2014. Ljubljana. MO RS.

26. Pišlar, M., 2015. Streljali z minometi 60 milimetrov. Revija SV, 9. september 2015. Ljubljana: $M O R S$.

27. Stanimirovič, M., 1973. Minobacač $60 \mathrm{~mm}$ M57 sa tablicama gađanja. SSNO, Vojna štamparija, Beograd.

28. Vlada RS, 2013. Srednjeročni obrambni program Republike Slovenije 2013 - 2018. Ljubljana: št. 80300-1/2013/3 z dne 1. 2. 2013.

29. Žabkar, A., 2007. Pehotna oborožitev in oprema - stanje in smeri razvoja. Založba Defensor, Ljubljana.

30. Armee de Terre, Organisation des forces, Artillerie http://www.defense.gouv.fr/terre/ presentation/organisation-des-forces/artillerie/40e-regiment-d-artillerie (16. 10. 2015).

31. Otmann, S., New Russian Brigade TO\&E; http://defense-and-freedom.blogspot. com/2009/10/new-russian-brigade-to.html (23. 6. 2015).

32. Pilatus PC-9M Hudournik, http://www.slovenskavojska.si/oborozitev-in-oprema/letala-inhelikopterji/pilatus-pc-9m-hudournik/ (16. 10. 2015).

33. The British Army, Armoured Infantry Brigade Organisation http://www.armedforces. co.uk/army/listings/l0013.html (23. 6. 2015).

34. The British Army, Battlegroups And Company Groups/Task Group http://www. armedforces.co.uk/army/listings/l0014.html (23. 6. 2015).

35. The British Army, Heavy Protected Mobility Battalion http://www.armedforces.co.uk/ army/listings/l0030.html (23. 6. 2015).

36. The British Army, Light Protected Mobility Battalion http://www.armedforces.co.uk/army/ listings/l0031.html (23. 6. 2015).

37. The North Atlantic Teraty na http://www.nato.int/nato_static/assets/pdf/stock publications/20120822_nato_treaty_en_light_2009.pdf (16.1. 2015). 
Priloga 1:

Stanje v SV

Appendix 1:

Situation

in the SAF
凶

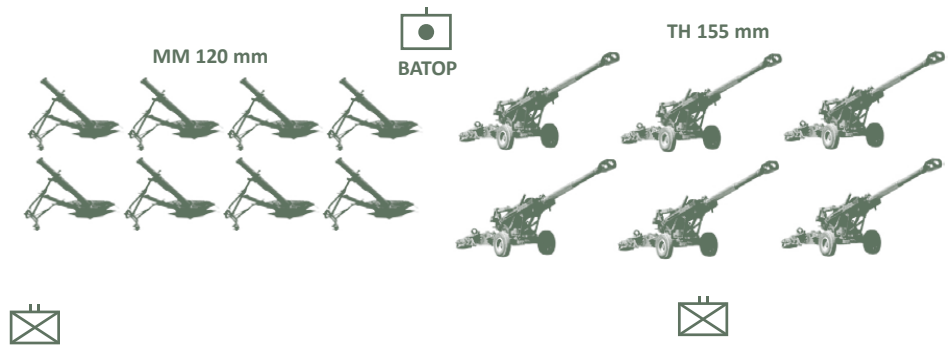

艾

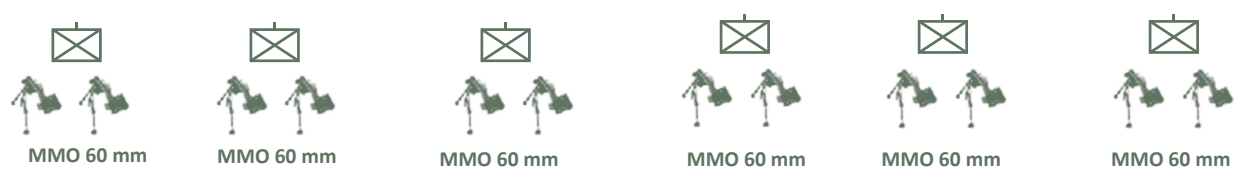

Priloga 2:

Predlog razvoja

Appendix 2:

Development proposal

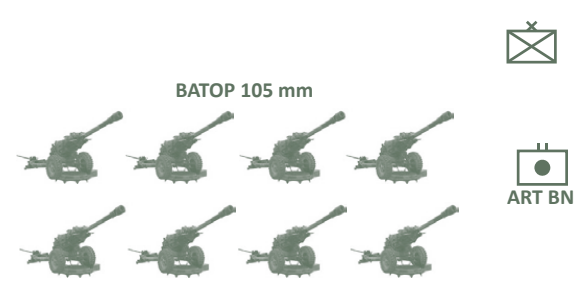

芉

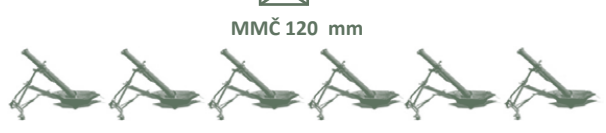

㐫

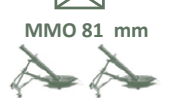

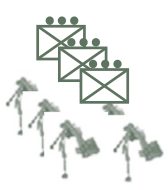

MMO $60 \mathrm{~mm}$
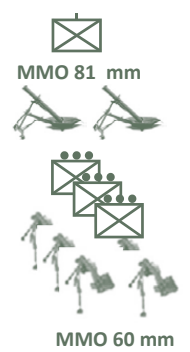

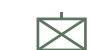

mino

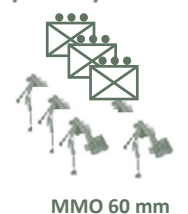

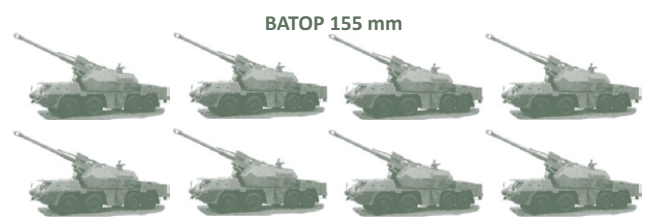

芉

MMČ $120 \mathrm{~mm}$

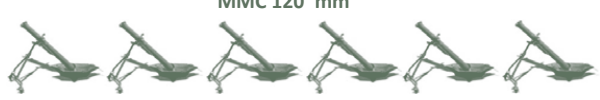

㐫

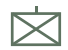

㐫
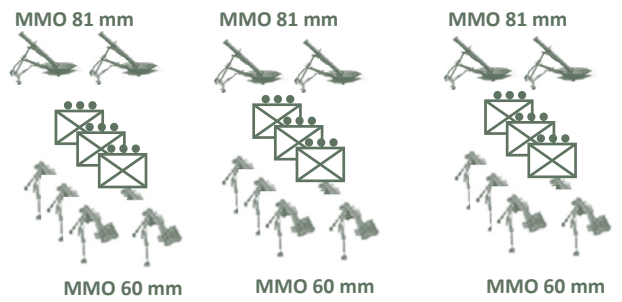


\section{Priloga 3:}

Predlog izboljšanja sedanjega stanja Appendix 3: Proposal for the improvement of the current situation
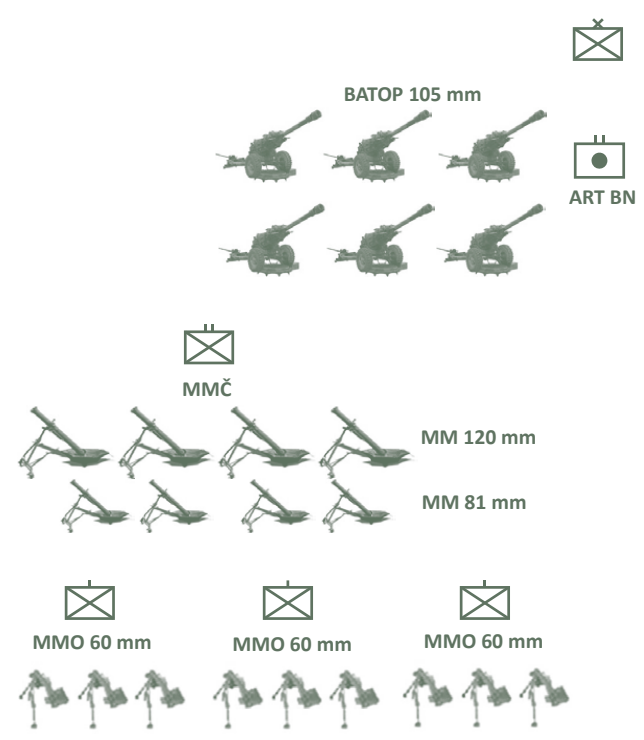
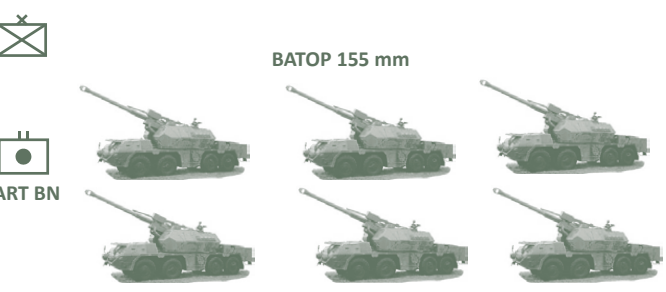

凶
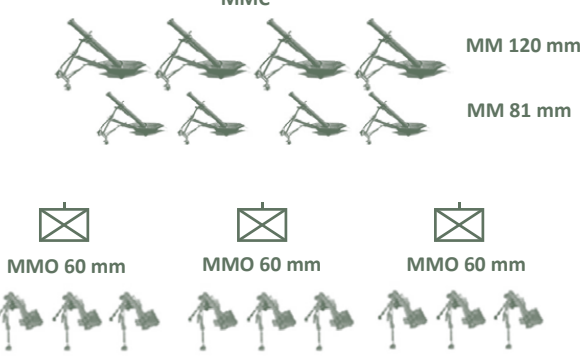

Priloga 4:

Pehotna brigada kopenske vojske ZDA

Appendix 4: Infantry Brigade, US Army
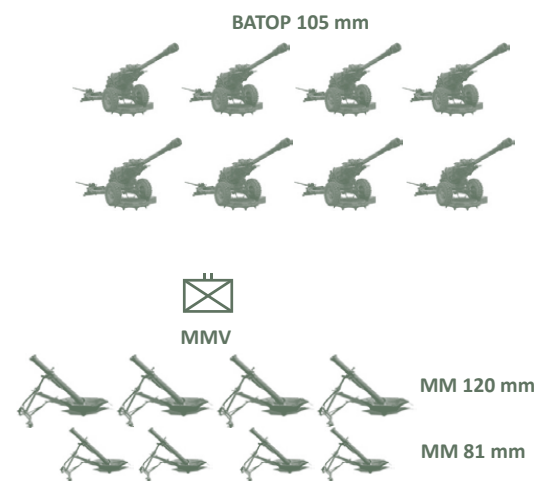

㐫

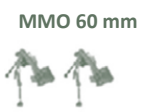

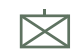

MMO $60 \mathrm{~mm}$

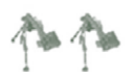

㐫

MMO $60 \mathrm{~mm}$

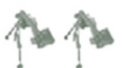

$凶$
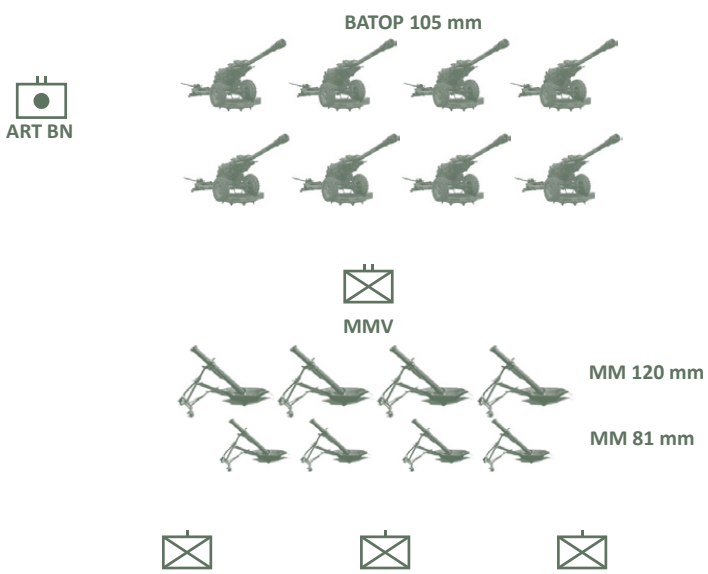

MMO $60 \mathrm{~mm}$

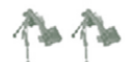

MMO $60 \mathrm{~mm}$

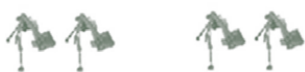




\section{Priloga 5:}

Brigada

britanske

kopenske vojske

Appendix 5:

Brigade, British

Army $\ddot{凶}$

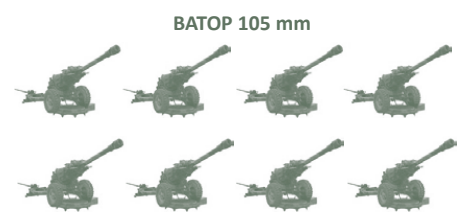

$\underset{\text { ART BN }}{\bullet}$

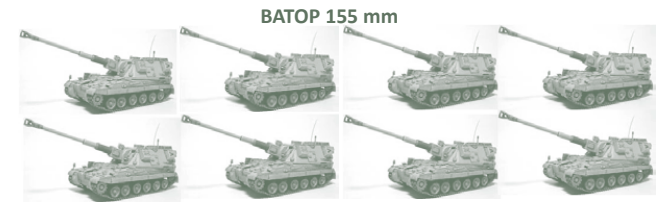

凶
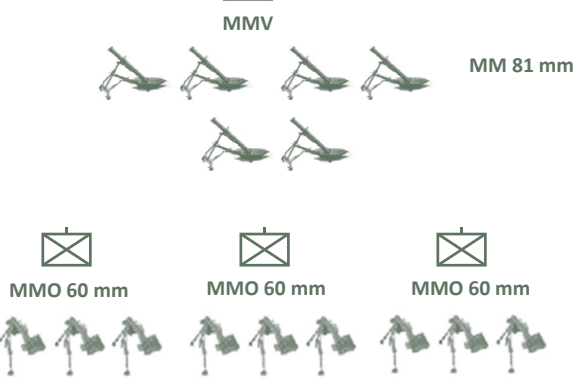

Priloga 6:

Brigada

kopenske vojske

Ruske federacije

Appendix 6:

Brigade,

Ground Forces

of the Russian

Federation
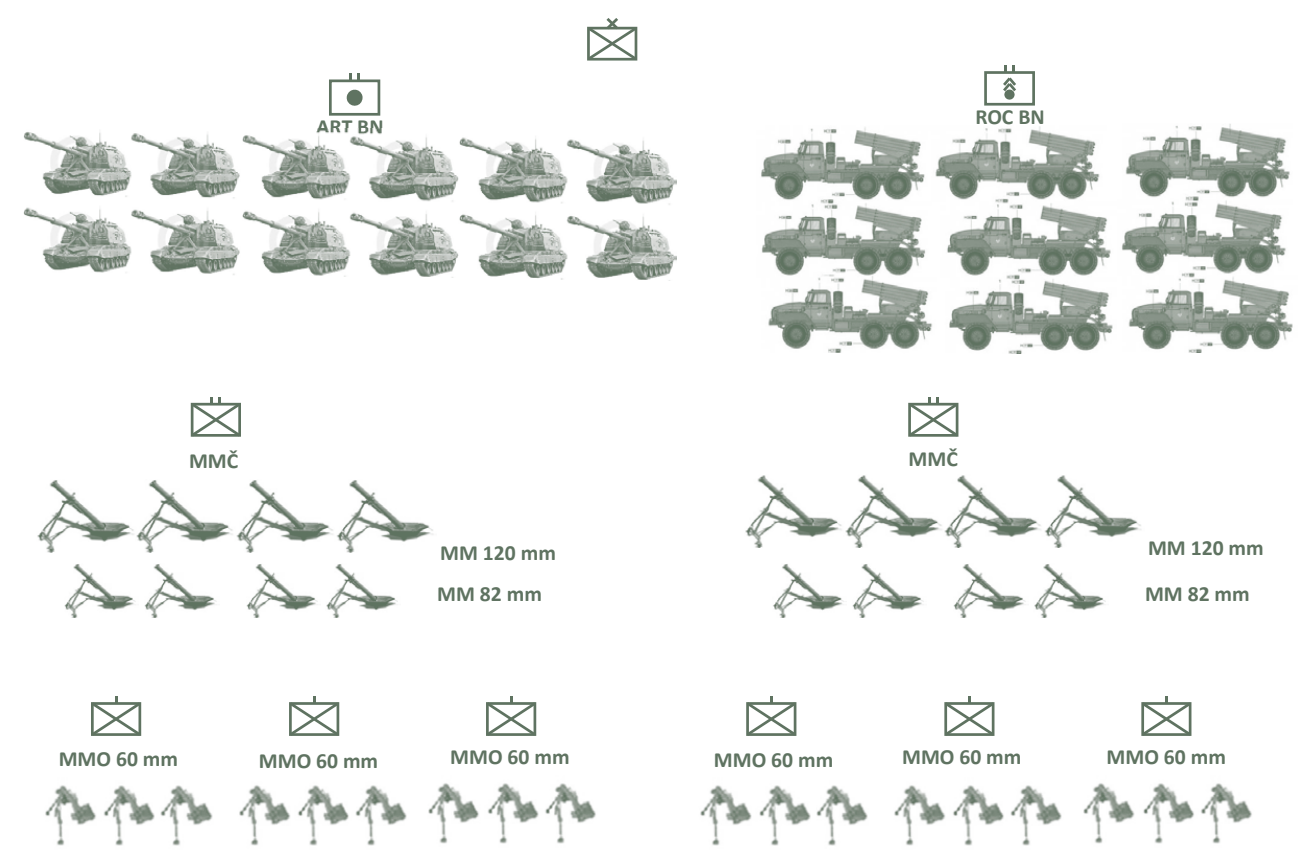